\title{
Cement Produciton Externalities and Profitability of Crop Enterprises in Two Local Government Areas of Ogun State
}

\author{
A. A. Tijani, O. Ajobo and A. A. Akinola \\ Department of Agricultural Economics, Obafemi Awolowo University, Ile- Ife, Nigeria \\ E-mail: aatijani@yahoo.com
}

KEYWORDS Cement; externalities; profitability; crop enterprises

\begin{abstract}
This paper examines the effect of externalities (environmental pollution) generated by the activities of the West African Portland Cement Company (WAPCO) PLC in its two plants at Sagamu and Ewekoro on the profitability of Agricultural production in its areas of operation. To this end, study area is divided into two areas- those affected by the operation of the factories, and those not affected (control). Farmers were selected from each area for interview by means of a probabilistic sampling technique. Information was collected by means of a pre-tested structured questionnaire from both sets of respondents. Costs and returns were estimated for farmers located in each area; then the probability of farm enterprises as well as the efficiency of resource utilization in the affected area was compared with those in the control area. The study shows that (i) the main environmental pollutants generated by the company are dust and noise; thus the inhabitants suffer from air-laden air, cracking of walls of structures as well as soil and water polluted by dust; (ii) farming was more profitable in the control than in the affected area in both zones: For example, the estimated net returns accruing to an average farmer in the affected area was \#190,524.25 per hectare while that in the control area was \#272,282.20 per hectare; (iii) resource productivity was higher in the control area than in the affected area. For example, farmers in the control area earned N4.72 for every N1.00 expended on labour while their counterparts in the affected area earned N2.18; and (iv) farmers in the affected area incurred additional costs in purifying their water for drinking, attending to their health problems resulting from the activities of the company and effecting repairs on their cracked buildings. The estimated average cost incurred was N24,000 per annum. These findings imply that the operations of the company have negative effects on the profitability of farm production as well as the productivity of agricultural resources in the areas affected by its production activities. Hence, the study suggests that the relevant government agency, Federal Environmental Protection Agency (FEPA), should (i) ensure that the company compensates the affected farmers for the damages suffered and (ii) review the maximum permissible dust and noise emission levels in order to reduce the adverse effects of cement production in the study area.
\end{abstract}

\section{INTRODUCTION}

There are seven cement producing companies in Nigeria operating eight works. The West African Portland Cement Company is currently the leader in the industry; its two operating factories with combined installed capacity of 1.6 million tonnes of cement per annum. The two factories are at Ewekoro (located at kilometer 64 on Lagos - Abeokuta road) and at Shagamu on the outskirts of Shagamu town on the old IbadanLagos road

These two cement factories which are surrounded by both residential areas and farm holdings are selected for this study because of the complaints from the residents and farmers of the deleterious effect of cement dust on their health, buildings and their means of livelihood.

Hence, there is the need to investigate how beneficial or otherwise is the existence of these factories to the majority of the inhabitants in the immediate localities. This is an issue in environmental economics.
Environmental economics is in its infancy in Nigeria probably because our economy is still regarded as principally agricultural in nature. Even in the petroleum industry where environmental pollution is so glaring, emphasis has been on non-economic issues, hence the political agitation for huge compensations and rehabilitation/amelioration of oil producing environments. Serious in-depth economic studies need to be undertaken in respect of environment degrading activities in oil prospecting, manufacturing and even agricultural ventures so that the nation will be well informed about what policy measures to take to achieve reasonable balance between economic growth and development on the one hand and permissible environmental degradation on the other.

Study Objective: The objective of this study therefore is an analysis of the external economies and/ or diseconomies, if any, on agriculture in Ewekoro and Shagamu localities resulting from the existence of WAPCO's cement plants in these areas. This is achieved by estimating the relative 
productivity of agriculture and hence income of farmers in cement dust polluted compared to unpolluted areas of Ewekoro and Shagamu.

Hypothesis: The hypothesis (Ho) therefore tested in this study is that the activities of the cement works do not have negative effects on the profitability/viability of agricultural production in their areas of operation.

The alternative hypothesis ( $\mathrm{Ha}$ ) is that the cement company's operations have negative effects on the income and hence the standard of living of farmers in the study area.

\section{LITERATURE REVIEW}

The major cement industry pollutant is dust. Of the many side effects provoked by cement production activities, the most important and costly are the following:

(i) reduction in crop yield (Salao et al., 1993;

Rao and Narayanan, 1998; Liu et al., 1997).

For example, Liu et al. (1997) reported that cement dust decreased the yield of grape and rice in the vicinity of a cement factory in China.

(ii) reduction in soil fertility (Sivakumar and Britto, 1995; Adejumo et al., 1994). Adejumo et al. (1994) showed that some toxic heavy metals like arsenic (AS), lead ( $\mathrm{Pb}$, nickel (Ni), cobbalt $(\mathrm{Co})$, zinc $(\mathrm{Zn})$, copper $(\mathrm{Cu})$ and phosphorus $(\mathrm{P})$ were significantly enriched in the neighbourhood of cement factories in Nigeria

(iii) destruction of vegetation cover and environmental degradation (Topie, 1999; Hegazy ,1996; Raguotis, 1997). For example, Topie (1999) indicated that the cement industry was the main cause of destruction of vegetation cover and of environmental degradation in Solin and Kastela near Spilt, Croatia. Damages to coniferous trees by cement dust have been reported by Mandre and Tuulmets (1997)

(iv) acute or chronic health effects; (Syamala and Rao, 1999; Adejumo et al., 1994; Fernandez et al., 1998). Toxic heavy metals listed in (ii) above have been found to have serious health consequences for man (Adejumo et al., 1994). According to Syamala and Rao (1999), man feeding on plants contaminated with mercury may suffer from mercury poisoning.

(v) damage to dwellings (Perfettini et al., 1989; Wasserbauer et al., 1998). Deposit of cement dust on roofs can cause microbiological and chemical disintegration of the roofs. Wasserbauer et al. (1998) indicated that metabolic process of nitrifying bacteria (mainly Nitrosomonas and Nitrobacter) on cement dust which settle on roofs can cause chemical corrosion of the roofing materials thereby increasing porosity and weakening the strength of roofing materials.

(vi) Pollution of water (Ademola, 1998; Zubareva et al., 1999). According to Ademola (1998) water quality is dependent on the total dissolved substances in it and these substances when dissolved in water react to change the alkalinity, $\mathrm{pH}$ and hardness of water. Hardness can affect the suitability of water for drinking or for use in steam boilers, water heaters, and in other industrial activities.

This review has indicated that not much work has been done in the economic quantification of these external effects, especially in Nigeria. Seems to be a dearth of economic studies on the external costs of cement production in Nigeria.

\section{MATERIALANDMETHODS}

Data Collection: Data for the study were collected with the aid of two different questionnaires. One was for farmers in the polluted area and other for farmers in the non-polluted (control) area. The questionnaires for farmers were administered by the investigators but with the help of agricultural extension agents who interpreted, where necessary, the questions into Yoruba, the language of the locality.

In order to obtain good information about the externalities created by cement production on agriculture in Shagamu and Ewekoro localities, the study area in each case was divided into two (i) area affected by the operations of the company (target) and (ii) area not directly affected by the operations of the cement company (control). The target areas comprise Shagamu, Iperu-Remo and Ewekoro while Ifo-Ota and twenty seven villages around Shagamu constituted the control area. A total of 132 respondents selected by simple random sampling technique were interviewed 71 in affected areas and 61 in the control areas.

Analytical Technique: Descriptive and budgetary methods are used to analyze the data collected. The descriptive methods include frequency tables, averages, percentages etc. 


\section{FINDINGS AND DISCUSSION}

Our analysis starts with an examination of and relevant conclusions in respect of major socioeconomic characteristics of respondents. These characteristics are age, farm size, level of education, system of farming, family size, years of farming experience and other sources of employment exhibited in our data.

Age Distribution: Table 1 depicts the age distribution of the respondents. The age range of the target group is 35 to 78 years with an average of 62 while that of the control group ranged from 25 to 65 years with an average of 44 years. The data therefore suggest that farming is left more in the hands of older people in the target area than in the control area. The most productive segment of the male population is not in agriculture in the target in contrast to the control area and this is likely to have undesirable implications on farm organization and hence agricultural production in the affected area.

Table 1: Distribution of respondents by age (in years)

\begin{tabular}{lrc}
\hline & Target & Control \\
\hline Mean & 62 & 44 \\
Minimum & 35 & 25 \\
Maximum & 78 & 65 \\
Modal range & $51-60$ & $41-50$ \\
\hline
\end{tabular}

Source: Field survey 2002

Years of Experience: More than half of the sampled farmers in both target and control areas have between 10 and 20 years of farming experience. The mean number of years of experience was 15 years in both the target and the control areas. This implies that there was no significant difference in the average years of farming experience between farmers in the target and control areas. In other words, differences in profitability of crop production between the target and control areas may not be attributed to differences in years of farming experience.

Level of Education: As expected the level of literacy is higher among the control than the target area respondents. $67.7 \%$ of the farmers in the control area can both read and write as compared with only $43.2 \%$ in the target area. This level of education attained by the farmers in the control area may indicate better chances for more productive agriculture and better farm organization and operation.

Distribution of Farm Size: Both target and control farmers have several plots scattered over different locations. The range for the target farmers' farm size is 0.13-10.4ha with a mean of 2.5ha while that for the control farmers is 0.4-6.0 hectares with a mean of 1.78 hectares. The modal class for the former is $0.5-1.0$ ha while it is $0.5-$ 1.5 ha for the latter. The survey reveals that $22.6 \%$ of the control farmers cultivate less than 1.0ha compared with $35.5 \%$ of the target farmers. This conforms with expectations as farmers in the target area are older and less energetic than their counterpart in the control area. Also, the complaints of the farmers in the target area about the effect of WAPCO's activities on agricultural production and their dwellings may be responsible for lower level of investment in agriculture in the polluted area.

Family Size: The average number of wives and children per farmer in the control area are two and seven, respectively while the corresponding figures in the control area are two and six, respectively. This indicates a relatively large family size in both areas; this which may be attributed to economic reasons - savings on labour wages and enhanced production capacity. In other words, differences in productive capacity between the target and control areas may not be attributed to differences in family size.

System of Farming: About one-third $(32.26 \%)$ of the target farmers practice monocropping in contrast to $0.00 \%$ in the control area. The areas that are more polluted by cement dust can only support cassava while the less polluted area can support other crops hence the popularity of mono-cropping in the target area. The remaining two-thirds of the target farmers practice intercropping so as to (i) spread the cost of cultivation on many crops; (ii) avert the risk of losing the only one crop in case of unanticipated hazard and (iii) ensure a variety of food items for family consumption. All the farmers interviewed in the control area practice intercropping as most of them explained that the cost of production is spread on more enterprises and the risk of losing the whole crop (in case of pestilence) is averted by practicing intercropping.

The foregoing implies that investment in agriculture faces demonstrably a greater risk in the polluted than in the less polluted area, as farmers are exposed to greater fluctuation in production and income in the affected area. In other words, there is a greater likelihood of farm income variability in the affected than the control 
Table 2: Budgetary analysis of enterprises in polluted and control areas.

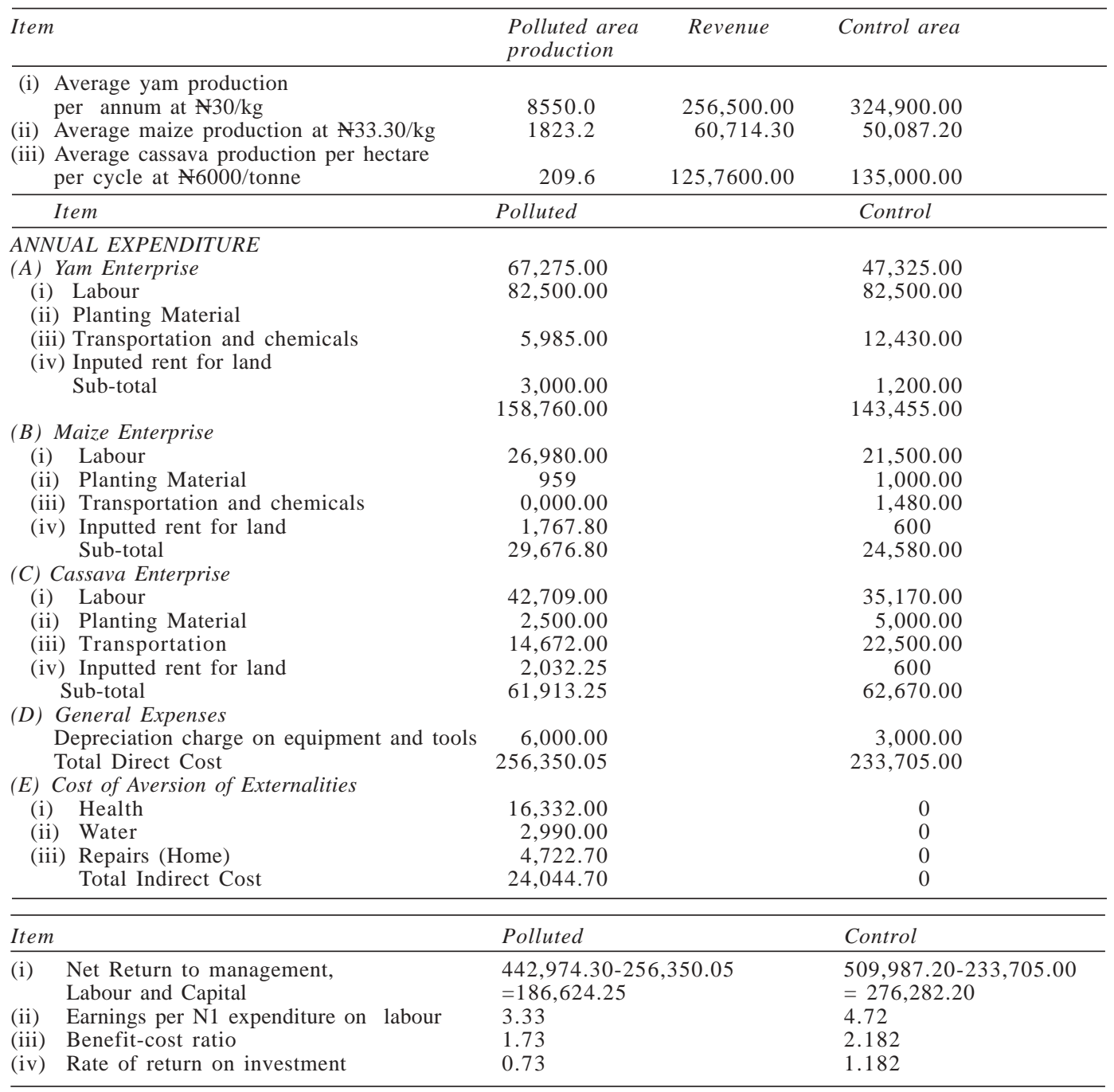

Source: Data analysis

area. Hence agricultural production should, theoretically, be more profitable in the polluted than in the less polluted areas.

Estimated Costs and Returns: Costs and returns estimated for the target and control groups are presented in Table 2. The purpose of estimating these costs and returns is to determine the effect of externalities generated by cement production activities on the profitability and efficiency of farm production in the study area.

The results reveal that the earnings (revenue) per hectare are higher for control farmers than their target counterparts. This may mean that productivity of land in the target area is lower than that in the control area because of the activities of WAPCO. Farmers in the control area also enjoyed lower cost of production than their counterparts in the target area; hence there was higher profitability of farm operations in the less polluted area than polluted area. The net returns enjoyed by control farmers are N272, 282.20 as against N166, 472.55 per hectare realized by target farmers. This is an indication of the negative externalities generated by the activities of the 
cement company. These are the real costs of (i) poorer quality of soil, (ii) deposition of cement dust on plant leaves (which lowers their level of photosynthetic activities), (iii) pollution of water and air by dust (iv) mandays lost due to health problems and (v) weakening of foundations, cracking of walls and eventual collapse of buildings arising from continuous blasting of limestone.

The earnings per $\mathrm{N} 1$ expenditure on labour in the target area is 2.23 as opposed to 4.72 recorded in the control area. For every $\mathrm{N} 1$ expended on crop production N 1.73 and N 2.18 are realized in the target and control areas respectively. Also, the net income per $\mathrm{N} 1$ expenditure on crop production is $\mathrm{N} 0.73$ and $\mathrm{N}$ 1.18 in the two respective area (Table 2).

The estimated net return to management, capital and labour in the target area was N166, 479.55 per hectare which is considerably lower than N272,282.20 obtained in the control area. This is not unexpected as the externalities generated by the production activities of WAPCO is expected to

(i) Impose additional costs on the affected farmers to avert these externalities. This is estimated to be N24, 044.70 (per farmer) per annum in the polluted area..

(ii) engender loss of labour, which may be total or a partial through sickness of a farmer or that member of his family nursing him

(iii) reduce time allocated to farm operations (by affected farmers) because of travel time to collect and prepare herbs ( for traditional medication) or visit clinics to cure cement dust-related illnesses

(iv) increase farm production risk- when dust pollution affects the health of household members it increases perturbations in available labour resource which in turn introduces some degree of uncertainty into farm production efforts.

\section{SUMMARY}

The objective of this paper is to analyze the external economies or diseconomies (if any) on agriculture in Shagamu and Ewekoro resulting from the activities of WAPCO's two cement works in the two towns. The immediate environs of Shagamu and Ewekoro were chosen as the target area while some towns and villages a little distance away were taken as control area for this study. Simple random sampling procedure used to select respondents in both areas for interview. Descriptive statistics and budgetary methods were used to analyze the data collected. The major findings are as follows:

(i) The majority of farmers in the polluted area are within 51-60 age bracket while the modal age bracket of those in the control area is 41-50 years. This implies that the most productive age group was not involved in farm production in the affected area due probably to alternative wage employment provided by WAPCO and other companies situated in Shagamu and Ewekoro.

(ii) Farm production risk seems higher in the affected than in the control area as soils in the affected area could only support cassava production in most cases.

(iii) The cost of crop production per hectare $(\mathrm{N}$ $252,450.00)$ was higher in the affected area than that (N235,705.00) in the control area.

(iv) The estimated cost incurred in eliminating the externalities associated with cement pollution by an average farmer in the affected area was N24, 044.70 per annum.

(v) Farmers in the affected area recorded comparatively lower crop outputs per hectare and hence lower earnings than their counterparts in the control area.

(vi) farm production was more profitable in the control than in affected area. The net farm income per hectare in the control area was N 272,282.20. as opposed to N190,524.24 in the affected area.

(vii) earnings of labour per hectare per N1 expenditure was 4.72 in the control area while it was only 2.23 in the affected area. In other words, labour contributes more to the value of output in the control than in the affected area.

\section{CONCLUSION}

The results of this study suggest that the production activities of West African Portland Cement Company have demonstrably negative effects on agricultural production in the area of study. The study therefore suggests that (i) the permissible dust emission level should be reviewed by Nigeria's policy makers so that, in the long run, the adverse effects of cement dust pollution on agricultural production will be reduced in the study area and (ii) in the short run, the company should be made to compensate 
the affected farmers for the costs incurred in averting the external diseconomies generated by the activities of its factories.

\section{REFERENCES}

Adejumo, J.A., I. B. Obioh, O. J. Ogunsola, F. A. Akeredolu, H. B. Olaniyi, O. I. Asubiojo, A. F. Oluwole, O. A. Akanle and N. M. Spyrou. 1994. "The Atmospheric Deposition of major, minor and trace elements within and around three cement factories." Journal of Radio Analytical and Nuclear Chemistry, 179(2): 195-204

Ademola, I.1998. Water Pollution Around WAPCO Cement Works Ewekoro. Ibadan, Nigeria: University of Ibadan.

Fernandez, E.A, E. Leontsin, C. Sherman, A.S.T. Chen, C.E. Reyes, R.C. Lozano, B.A. Fuentes, M. Witcher and P.J. Winch. 1998. "Trial of a community based Intervention to decrease infestation of Aedes aegypti mosquitoes in cement Wash basin in El Progresso, Honduras." Acta Tropica, 70 (2): 171183

Hegazy, A.K. 1996. "Effect of cement kiln dust pollution on the vegetation and seed bank species diversity in the eastern desert of Egypt." Environmental Conservation, 23(3): 249-252

Liu, J.L., Z. K. Du-Mei, X. Chenshuyuan and Y.Y. Ming. 1997. "The effects of Cement dust pollution on rice, grape and soil." Journal of Plant Resources and Environment, 6 (3): 42-47

Mandre, M and L. Tuulmets. 1997. "Biochemical diagnosis of forest decline." Baltic Forestry, 3 (2): $19-25$
Perfettini, J.V, N. Lango Mazino, E. Reverbegat, J.K. Petit, C.C. Gaylende and L.H.G. Mortan (eds). 1989. Evaluation of the Cement Degradation Induced by the Metabolic Products of Two Fungal Strains. Biodeterioration Society occasional Publication No 5.

Ragoutis, A. 1997 "Stability of Forest Marshland Microflora within the impact zone of the Akmnes cement plant." Miskininkyste, 39(1): 128-138.

Rao, C.M. and A. Narayanan. 1998. "Growth of rice plants exposed to cement dust pollution." Journal of Research ANGRAH, 26(3-4): 11-14

Satao, R.N., H.K. Kene, R.V. Nalamwa and R.B. Ulemale. 1993. "Effect of cement dust Pollution on growth and yield of cotton." Annals of Plant Physiology, 7(1): 73-77.

Sivakumar, S. and A.J. Britto. 1995 "Effect of cement pollution on soil fertility." Journal of Ecotoxicology and Environmental Monitoring, 5(2): 147-149.

Syamala, D. and B.R.P. Rao. 1999. "Mercury accumulation in selected plant species exposed to cement dust pollution." Current Science, 76(8): 1075-1076.

Topie, V. 1999. "Surface excavation in the area of kastela and the possibilities of Amelioration." Surmarki List, 123(7-8): 301-309.

Wasserbauer, R, Z. Zadak and J. Novotry. 1998. "Nitrifying bacteria on the asbestos cement roots of stable buildings." International Biodeterioration, 24(3): $153-165$

Zubareva, O.N., L.N. Skripal'shoch and K. Perevozn. 1999. "Dust accumulation by components of the birch Phytocenoses in the zone of lime stone quarries." Russian Journal of Ecology, 30(5): 308312. 